\title{
The importance of heritage conservation in architectural education at university level
}

\author{
Krystyna Kirschke \\ https://orcid.org/0000-0003-4278-263X \\ krystyna.kirschke@pwr.edu.pl \\ Faculty of Architecture, Wroclaw University of Science \& Technology
}

\begin{abstract}
The subject of the article covers analyses of the methods and effects of architectural and conservation education at the university level on the basis of the research results of the Erasmus + SURE project and our own experience in creating and implementing conservation curricula at the Faculty of Architecture of Wroclaw University of Science and Technology. The observations concerning the works sent to the Professor Jan Zachwatowicz International Competition (ICOMOS Poland), in which master's diploma projects on the protection and restoration of architectural monuments were evaluated, were presented as a comparative material. It is a place of confrontation of the effects of teaching in the majors of architecture and heritage conservation, which shows differences in systems and methods of teaching at universities. This made it possible to draw conclusions regarding education in the specialization of architecture and urban planning as well as to outline necessary program changes, some of which were successfully implemented in Poland in 2020, by introducing a new core curriculum.
\end{abstract}

Keywords: architectural heritage conservation, adaptive reuse, architectural education, monuments preservation

\section{Introduction}

For decades, scientists and architects have been dealing with the topic of teaching cultural heritage and broadly understood monument protection, especially in cities [1, 2]. Conferences, seminars and workshops have been held on this subject and series of specialist publications are created. The dynamically changing theory and practice of conservation as well as the expanding number of protected objects mean that the demand for professionally prepared conservators-architects is also constantly growing due to the fact that most graduates will carry out such orders as renovation, modernization, reconstruction and expansion, as well as restorations and revitalizations $[3,4]$. That is why teaching conservation methods that will help to learn the basic principles and criteria of architectural evaluation is so important for students. This requires improvement of the traditional pattern of education, which is based on models and theories not adapted to the changing situation. Future architects come into contact with the so-called conservation design only at the end of their studies. Due to the limited number of classes, the program of this subject must be well-thought-out so that candidates for independent designers can see and recognize the constant values of historical architecture, regardless of the era in which it was created. They must treat a historic object as a kind of material document which must be thoroughly understood in order to be able to analyze it and draw the right conclusions. They should also master the basics of integrating old architecture with the new one in such a way as to preserve the maximum part of the historic structure. The final diploma theses constitute undoubtedly a test of how they were prepared for such activities during their studies. 


\section{Aims and Methods}

The article contains data and research results on architectural and conservation education systems which were applied at European universities and it outlines the need for changes in this area. It is based on studies of source literature and many years of teaching experience in conducting conservation classes at the Faculty of Architecture of Wroclaw University of Science and Technology (FA WUST) and on the research results of the international project SURE (Sustainable Urban Rehabilitation in Europe) $[5,6]$. In this project, through the analysis of curricula, the necessary knowledge and qualifications that students should acquire in order to be able to deal with the issues of heritage protection and urban regeneration in the future were determined. One of the basic methods of comparative assessment of the effects of education in the field of architecture and monument conservation takes into account the results of competitions for diploma theses, which is shown in the article by analyzing the results of the Professor Jan Zachwatowicz International Competition [7].

\section{Results}

\section{Conservatory teaching theory of architects and the legal basis}

The Convention for the Protection of the Architectural Heritage of Europe, signed in 1985 in Granada, and ratified in Poland in 2012, obliges us to provide specialist training for architects, urban planners, construction engineers and landscape architects [8] (pp. 65-68). According to article 11:

Due regard being had to the architectural and historical character of the heritage, each Party undertakes to foster:

- the use of protected properties in the light of the needs of contemporary life;

- the adaptation when appropriate of old buildings for new uses [8, p. 68].

In turn, Article 17 states that:

The Parties undertake to exchange information on their conservation policies concerning such matters as:

1. the methods to be adopted for the survey, protection and conservation of properties having regard to historic developments and to any increase in the number of properties concerned;

2. the ways in which the need to protect the architectural heritage can best be reconciled with the needs of contemporary economic, social and cultural activities;

3. the possibilities afforded by new technologies for identifying and recording the architectural heritage and combating the deterioration of materials as well as in the fields of scientific research, restoration work and methods of managing and promoting the heritage;

4. ways of promoting architectural creation as our age's contribution to the European heritage $[8$, p. 70$]$.

The convention was drawn up on the basis of previous recommendations of the Committee of Ministers to member states, one of which was the recommendation for specialized teaching of architects, urban planners, civil engineers and landscape architects, the key element of which should be projects [8, pp. 162-165].

The Heritage Management in Poland was established to carry out tasks related to the protection of cultural goods and cultural heritage, the structure of which was defined in 1990. It is mainly based on the Polish Constitution and the Act of 23 July 2003 on the protection and the care of monuments. Other acts linked directly with heritage protection and use are as follows: The Act of 7 July 1994 - the Construction Law and the Act of March 27, 2003 on the planning and spatial development [9].

Research and teaching objectives as well as the legal framework for the functioning of education at the university level were defined in Poland in the Act on Higher Education and Science of July 20, 2018 [10]. This act had a significant impact on the functioning of scientific disciplines, shaping the structure of the university 
as well as didactic programs and core curricula, which, after adjusting to the assumptions of new education standards are currently being implemented at all universities, including those educating architects.

\section{Architectural and conservation teaching systems in Europe}

At present, at the faculties of architecture at European universities, two-degree studies undergraduate (bachelor's qualification) and graduate (master's qualification) which were developed in the Bologna process in 1999, are carried out [11]. These reforms were later only slightly modified. In 2003 in Berlin, during the convention of participant states, it was considered purposeful to include doctoral studies as the third degree of education. Two years later, over a seminar in Salzburg, the basic postulates that should be met by doctoral studies in the European scientific space were formulated. In individual countries, cycles have different lengths, and above all, the programs are different, which also applies to conservation subjects. An attempt at finding a common multidisciplinary English-language Master's degree program, combining the areas of sustainable development, i.e. broadly understood architecture, urban planning and heritage protection with social issues, was undertaken as part of the SURE project. The first completed stage was to collect information about curricula at various universities, focusing on heritage protection and urban regeneration. The research results were thoroughly analyzed and described in the textbook [6]. The project contained information from 19 European and non-European countries which completed 36 questionnaires describing the system of educating architects in the field of heritage protection as of 2016. The analysis of architectural study programs shows that they are very different, which makes it difficult to draw common conclusions and develop a model curriculum, however, it highlights the gaps within them. Undergraduate education programs declare the development of universal creative architects who are able to create designs with a moderate degree of complexity. The acquired knowledge, competences and skills very poorly meet the specific requirements of a heritage protection specialist. More specialized study programs are available at the Master's degree level only. It was also noticed that such a system of studies, which was based on three cycles of education and divided the academic year into semesters, reduced the time for acquiring knowledge, which should be gained in the right order. The students have lost the capacity of studying and searching in libraries and archives, and consequently have lost the capacity of reading the architecture reality $[6, \mathrm{p} .72]$.

It should be noticed that in view of these facts, some academic centers have been successfully conducting conservation specialties during the Master's degree studies for many years. In Poland, the first studies of this kind appeared in 1976 at the Faculty of Architecture of Warsaw University of Technology (FA WUT) and a year later at the Faculty of Architecture of Wroclaw University of Science and Technology (FA WUST). Their extensive theoretical program was connected with specialized knowledge of research methods and conservation technologies. At the same time, students were limited from the possibility of acquiring other elements of theoretical and professional education of an architect, for example the ability to design public buildings with a greater degree of complexity of functions and to understand the relationship between conservation and infrastructural issues [12]. In many cases, this disproportion was evident in the diploma exams during the presentation of final papers.

Gaps in conservation and engineering knowledge can be made up for during postgraduate studies. Such a system of improving qualifications mostly covers not only architects, but also all professional groups working for the protection of cultural heritage, which means that they also learn from each other. The implementation of this need, resulting from the will to institutionalize and internationalize the holistic teaching of conservation at the highest level, was the foundation of Raymond Lemaire International Center for Conservation, which provided the degree of "Master of Science in Conservation of Monuments and Sites", in Belgium in 1976 [13, 14]. It trains graduates with varying professional experience in heritage valuation and management. Also in Poland, postgraduate studies in scientific centers constitute an important opportunity to educate conservators. The Study of Cultural Heritage Protection, which was opened by Professor Jan Zachwatowicz at FA WUT in 1970, has the longest tradition. Postgraduate Studies in the Conservation of Monuments of Architecture and Urban Planning were established at Cracow University of Technology in 1973, and Postgraduate Studies in Monuments and Conservation of Historical Architecture at the University of Torun. This kind of study also functioned in the years 1987-1992 at FA WUST. 


\section{Architectural and conservation competitions for the best diploma theses}

As already mentioned, one of the possibilities of comparing the effects of conservation education of future architects are competitions for diploma theses, which give young designers an opportunity to check and compare their achievements against the background of graduates of various universities. One of the oldest and most prestigious European competitions aimed at young architects and students is the German Schinkel-Competition [15]. It was organized for the first time in 1852 and according to the formula, winning the competition was tantamount to obtaining a diploma of graduation from the Bauakademie in Berlin and its successor Technischen Hochschule Charlottenburg. At present, the competition takes place in various categories, including those related to the protection of heritage [16]. The most important competitions on such subjects include Fassa Bortolo Domus Restoration and Preservation - the international award which has been granted by the Faculty of Architecture of the University of Ferrara since 2010. Every other year, diploma projects related to the protection of cultural heritage, which refer to contemporary forms of expression, compete for it [17]. Other thematic competitions include Medal for Best Diploma Project, which currently functions as Young Talent Architecture Award (YTAA) under the European Union Prize for Contemporary Architecture - Mies van der Rohe Award and Zbyszko Zawistowski Diploma of the Year Award organized since 1964 under the auspices of the Association of Polish Architects [18].

The best master's theses of students, dealing exclusively with the issues of protection of cultural heritage, are selected in The Professor Jan Zachwatowicz international competition which was established in 1984. Initially, it was organized in separate categories, i.e. national and international. In 1987 it was suspended for financial reasons, but it was reactivated in 1995 [19, pp. 390-391]. Since 2000, the competition has been organized by PKN ICOMOS Poland with the participation of Krystyna Zachwatowicz-Wajda and director Andrzej Wajda (who died in 2016). The aim of the Competition is to promote and internationalize the issues of cultural heritage protection among students of architectural, artistic and conservation universities, in reference to the ideas promoted by Professor Jan Zachwatowicz (1900-1983). The patron of the competition is a distinguished figure for the cultural heritage of Poland. He was an architect and a researcher with enormous achievements, and was connected with the scientific community in Poland and abroad. As the General Conservator of Poland in the years 1945-1947, he implemented the program of complete reconstruction of destroyed monuments and old town centers $[20,21]$. Such creative reconstructions were not unequivocally accepted, as the Athens Charter guidelines of 1931 were still in force after World War II [22]. The Charter contained theories limiting the use of the reconstruction method, which was to prevent the relics from being rendered authentic. Zachwatowicz opposed these views in his program, which assumed the reconstruction of key monuments, and stated that "Of course, in the sublime conservation science this is a regression of many decades, but on our soil, it is the only way to proceed" [20, p. 52]. He recognized that "The matter of monuments is a fundamental social issue - the issue of the nation's culture. We cannot apply a unilaterally abstract theory to them, but we must take into account the needs of today. Only then will we find a social response and win the great thing of culture" [20, p. 52]. Another convention, The Venice Charter of 1964, one of which was signed by Jan Zachwatowicz, continued to recognize restoration and reconstruction as methods outside of conservation activities [23]. However, looking at this issue from today's perspective, we can see the rightness of the decision to reconstruct monuments "from the foundations in order to pass them on to generations" [20, p. 48]. It may have resulted from an emotional need, but as a consequence it was an important element in the renewal of society after the traumatic war experiences [21].

The works, which are sent to the Jan Zachwatowicz competition, are performed at universities of various profiles, mostly at the faculties of architecture, but also landscape architecture, and at departments educating titular conservators dealing with mobile objects. Projects by Polish graduates predominate, however, representatives of the European Union countries (Lithuania, Belgium, Bulgaria, Spain) and from beyond (Ukraine, Belarus) were also among winners. The diplomas are evaluated in three categories, i.e. 1. Historical and conservation research, protection methods, conservation of objects, their elements and details. 2. Revalorization, adaptation and modernization of historic structures (historic complexes and objects, historic urban and rural structures) and 3. Protection of cultural landscape, historic parks and gardens [7]. This division became necessary because the scope of the works presented is really diversified. For example, at universities which educate specialists dealing with mobile objects, the final works are prepared by students under the supervision of their promoters for 
even several years and, as a rule, they use conservative conservation methods with the limited use of modern forms or technologies. On the other extreme, there are architectural and conservation works described in this article. They are developed within a maximum of two semesters, during which the history of the place, object and its transformation is researched, an inventory of the state of preservation is made, an analysis of materials is carried out and a query is carried out independently by other people (experts), and the candidate focuses on generating a conservation program and its processing into an architectural and construction project. It usually assumes the adaptation of a historical object or complex to a modern function in terms of utility and adding to the existing contemporary tissue which fits into the identities of the place. The works show a great influence of promoters who guide the research and also promote their conservation views and architectural ideas.

When analyzing the works which were sent to the Professor Jan Zachwatowicz competition in recent years, positive changes can be observed. They are most visible in the diplomas from the European Union countries, especially in the theoretical part, where attention is paid to the conducted studies and research and the application of new technologies, implementing the principles of sustainable development [24]. In the works from outside the EU, it is not that clear. There is also a different level of elaboration, which may be related to the access to computer software which is used by students. In the years 2013-2020, the number of works varied between 25 and 58, and foreign works accounted for a small percentage. The first prize in the architecture category was not awarded as many as five times $(2013,2015,2017,2019,2020)$. Three Polish diplomas won the main prize: 2014 - Anna Pałgan (Fig. 1), 2016 - Mateusz Dołęga (Fig. 2), 2018 - Łukasz Erdmański (Fig. 3). The works of the winners of the Jan Zachwatowicz Competition received awards and distinctions in other prestigious competitions. Mateusz Dołęga, for the work "Museum of Steam Locomotives - Steam Center", in 2017 also received the first prize in the category of reconstruction and renovation of the facility in the XXVI International Exhibition-Contest of the Diploma Projects from Architectural and Fine Art Higher Education Institutions in Ivanofrankivsk [25]. The winners of the $2^{\text {nd }}$ and $3^{\text {rd }}$ prizes in the Jan Zachwatowicz Competition in 2017, Małgorzata Mader (Fig. 4) and Jakub Grabowski were also honored with the $1^{\text {st }}$ and $2^{\text {nd }}$ prizes in LafargeHolcim 2020, Next Generation Europe category [18, 26].

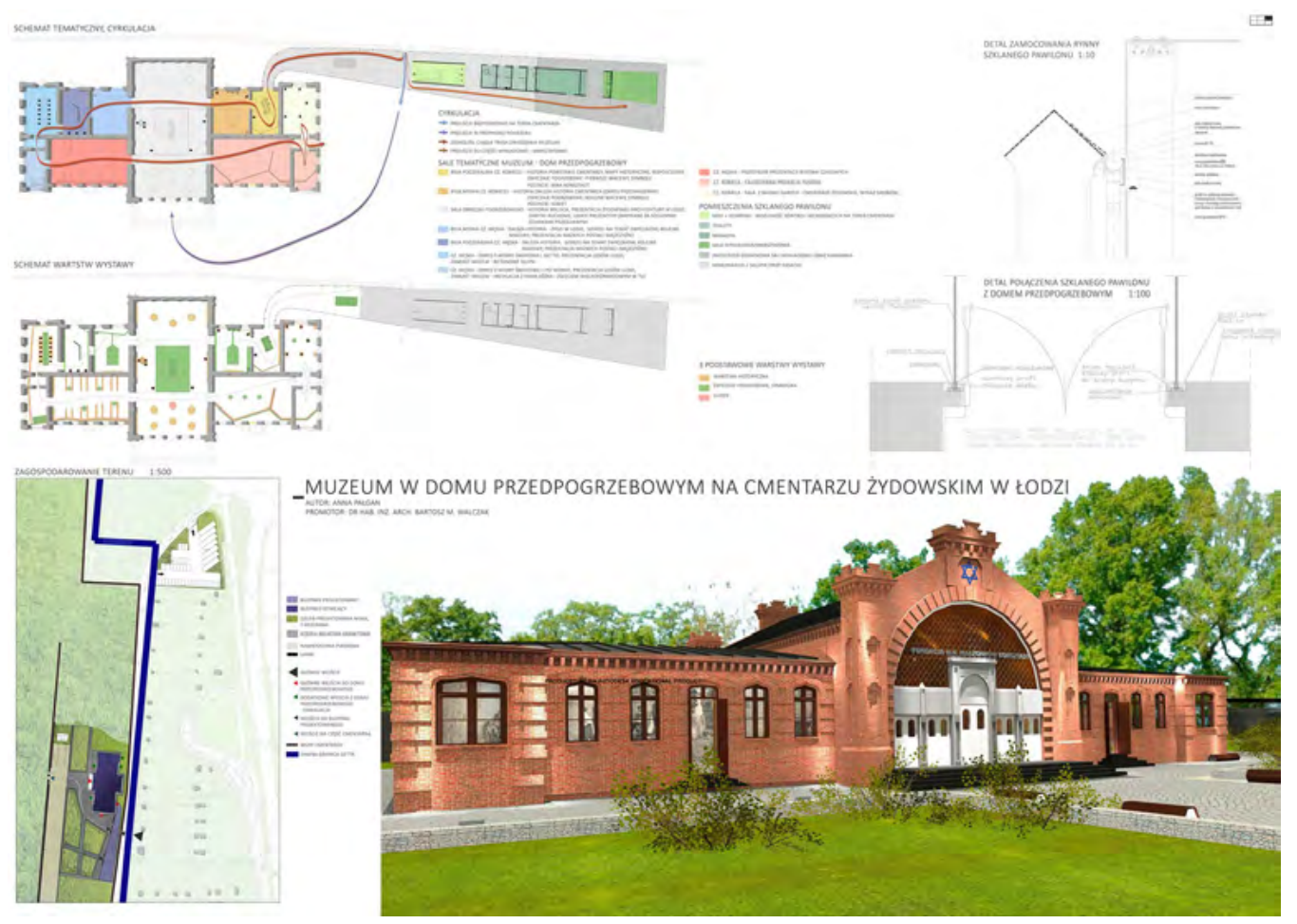

Fig. 1. First prize 2014. Anna Pałgan's diploma project "Museum in pre-burial hall of Jewish cemetery in Lodz". Faculty of Civil Engineering, Architecture and Environmental Engineering. Lodz University of Technology. Promoter: dr hab. inż. arch. Bartosz Walczak, prof. 


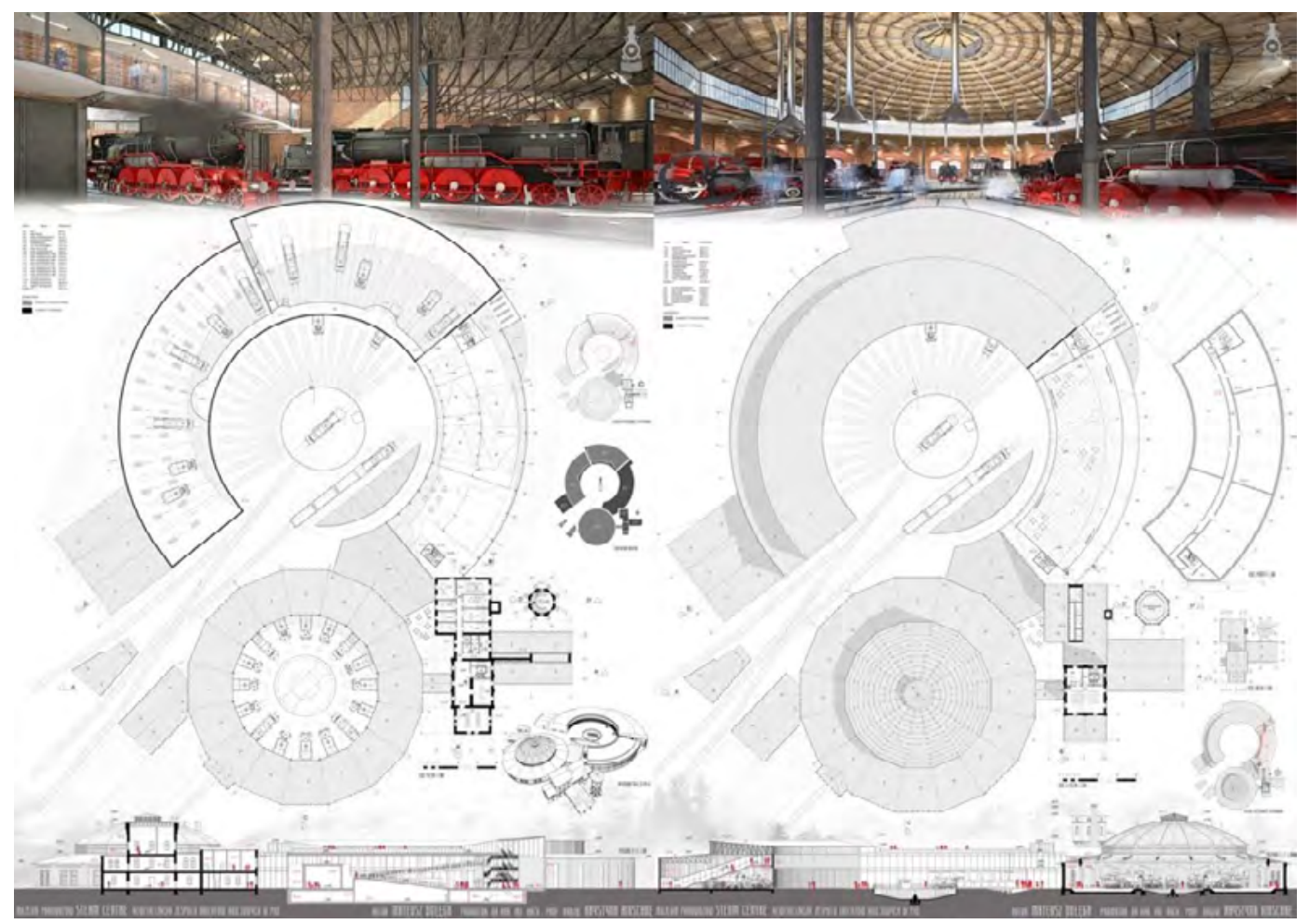

Fig. 2. First prize 2016. Mateusz Dołęga's diploma project "Museum of Steam Locomotives - Steam Center", Wroclaw University of Science and Technology. Promoter: dr. hab. inż. arch. Krystyna Kirschke, prof.

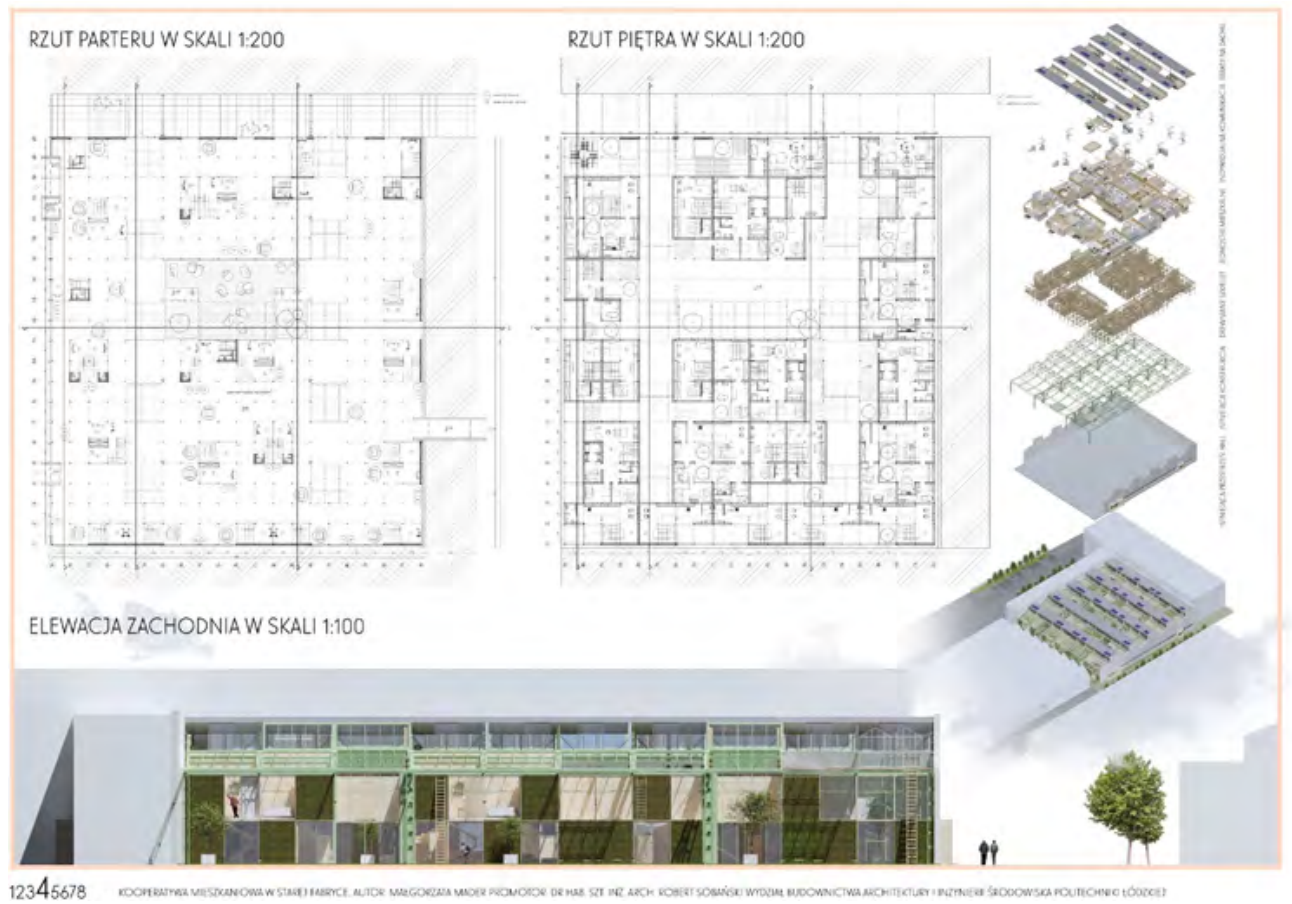

Fig. 3. Third prize in 2017. Malgorzata Mader's diploma project "A housing co-op in the Old Factory, or the adaptation of a 1960s single-space hall to a multi-family housing function." Lodz University of Technology. Promoter: dr. hab. szt. inż. arch. Robert Sobański, prof. 


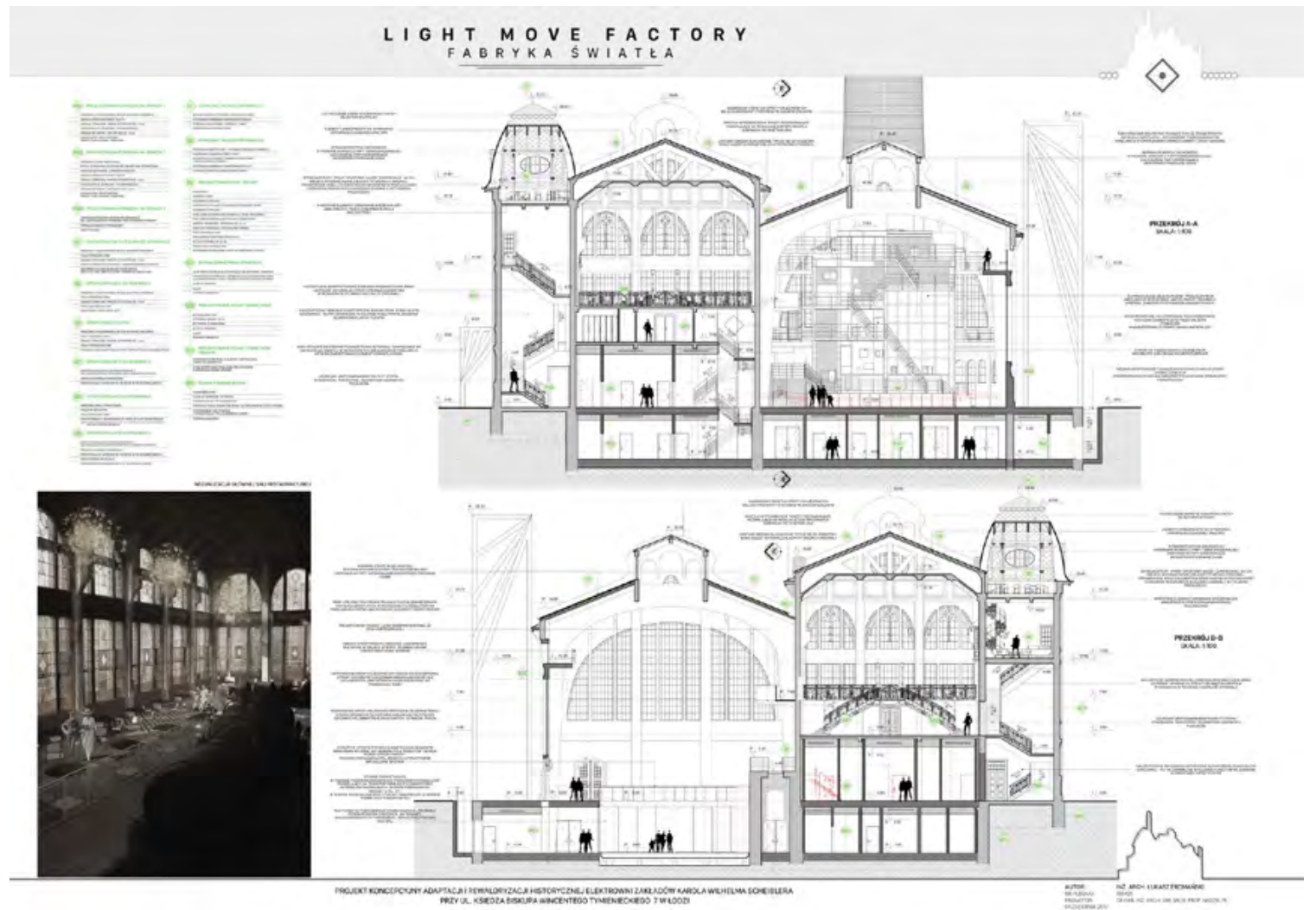

Fig. 4. Second prize in 2018. Łukasz Erdmański's diploma project "Conceptual project for the adaptation and revaluation of a historic power station of Karl Wilhelm Scheibler's factory located at 7 Biskupa Wincenta Tymienieckiego street in Lodz". Lodz University of Technology. Promoter: dr. hab. inż. arch. Jan Salm, prof.

\section{Discussion}

The education reform which was introduced in Poland in 2019 resulted in curriculum changes in the discipline of architecture and urban planning, which constituted the effects of new education standards and emphasized the strengthening of the role of design subjects [27]. Now, due to the Covid-19 pandemic, they are further verified by life. For three semesters now, design classes have been conducted online, which has been a challenge for teachers and students alike. Some universities have even seen the need to change their admissions system, deeming unnecessary the hand drawing exam, which has so far been treated as a test of a candidate's suitability for the architectural profession [28].

When introducing these new curricula, individual universities also tried to take into account the latest research results on the methodology of educating architects as well as urban planning, architectural and conservation theories and even ideas for modifications of teaching methods [29]. The participation of representatives of all leading departments of architecture and monument conservation in the jury of the Jan Zachwatowicz Competition was also of great importance.

In the 2020 revision of the curricula at FA WUST, at the $1^{\text {st }}$ degree of studies, elective blocks in urban and architectural design were introduced and the scope of strictly conservation subjects was limited to obligatory lectures and seminars on the history and theory of architecture. It was recognized that a key role in the architect's engineering training would be six-month design internships in offices, which were planned for the $7^{\text {th }}$ semester of studies. Thanks to this, people who are interested in conservation issues will be able to apply to studios dealing with monuments and there, in contact with professionals, gain the basics of specialized knowledge, which they can later deepen by continuing their education at the $2^{\text {nd }}$ degree studies. Within its 
framework, at the major of architecture, independent specializations were established, i.e. "architecture and urban planning", where $85 \%$ of students are educated as well as "architecture and monument protection". In the first specialization, the main emphasis was placed on theoretical knowledge in the scope of architectural engineering and acquiring the ability to convert it into complex construction projects. These classes include the participation of specialists in the field of conservation, which is advisable in situations when projects are created in connection with historical objects or the surroundings. Theoretical knowledge of general principles of conservation research and design is presented during a compulsory lecture, a seminar on the theory and history of architecture, and an urban and architectural project [30]. The latter includes revitalization of the historic quarter of buildings, renovation of the historic building (with the assumption of limiting interference with the valuable substance to those necessary for its survival and proper functioning), and the architectural and conservation project of the new building implemented in the historic environment [31, 32]. It is assumed that in the end, together with other large design classes carried out at the $2^{\text {nd }}$ degree of studies, it should provide all graduates with the basics of knowledge about the valorization of historical architecture, which is implemented on the basis of the sustainable architecture assumptions [33].

It should be added that the "architecture and monument protection" specialization includes integrated classes combining architectural and urban issues with conservation issues. As a result, during three semesters, students gain the skills which allow them to design comprehensively as well as they acquire specialist knowledge related to modern techniques of inventorying monuments, technological aspects and materials science. The test of acquired skills and competences as well as the confrontation of the effects of education in both specializations will constitute open defences of diploma theses conducted jointly.

\section{Conclusions}

The effects of the three-year research of the SURE project and the observations of the diplomas sent to the Professor Jan Zachwatowicz Competition, made from a juror's point of view, enable us to make the comments on the learning outcomes of students of architecture faculties implementing various conservation education programs.

The Professor Jan Zachwatowicz Competition gives young designers, planners and future conservators a good opportunity to test themselves in their fields and rank their skills as well as their achievements. In the works sent to the competition, the evolution of thinking about monuments is clearly visible. Interest is aroused due to the revalorization of centuries-old monuments, but no one is surprised by a diploma concerning the revitalization of an industrial facility from the $2^{\text {nd }}$ half of the $20^{\text {th }}$ century. It reflects the interests of promoters, which in turn results from professional practice, where the largest field of investment tasks is created precisely in relation to relatively new facilities but require a change of use.

There are two trends in the scope of conservation education of architects, i.e. the first related to the specialization in the protection of monuments and the other - architectural and urban specialization. The education process of the first type is focused on the theory of conservation and practical technology subjects, while minimizing design courses. Diplomas are based on students' own research and include professional theoretical studies, but the projects are limited to renovation or simple functional adaptations. In works embedded in the second trend, there is an attempt to achieve a balance between conservation analyses and a complex functional and spatial solution, which usually leads to solutions 8 referred to as "spectacle architecture" [34]. Works from this group were most often distinguished, which can be connected with the fact that they were also more graphically efficient. Technological projects, which are located on the other extreme, have a chance to win awards in the category of professional conservation research. This type of bipolarity proves that universities which provide the same title of "M.Sc. Eng.", educate students in ways which are incomparable. This can be considered as narrowing down education and restricting the possibilities of different paths of further work. This fact itself, however, is not a disadvantage because specialists, who are educated in such a different way, should be able to successfully cooperate in larger project teams.

Diploma theses in architecture and urban planning are carried out during the last semester because extensive master's degree programs do not provide any other options. If the project is related to conservation issues, this means that it is based on research conducted by other people, possibly supplemented by a graduate 
student under the supervision of the supervisor. It would be expedient for this type of work to reserve time during the penultimate semester for carrying out inventories and research leading to the articulation of authors' conservation guidelines.

In diploma projects, we should strive for integrated teaching leading to the development of skills to combine urban, architectural and conservation issues with the use of principles of sustainability in the scope of solutions such as technical, safety and comfort of use, accessibility for the disabled, as well as recycling and optimization of the energy balance of a given facility. In the case of revitalization projects, it is extremely important to be able to preserve the values and physical characteristics of "the old" to the maximum, which guides "the new" without overwhelming traces of the past. These effects are possible only in the case of a balanced study curriculum. Its elements should include appropriate master-student relations throughout the teaching process, a compulsory subject in the basics of conservation design during the $1^{\text {st }}$ degree studies and a preparatory semester for the diploma.

As it was already mentioned in the introduction, the doctrines, views and practice of performance in conservation are constantly evolving, the example of which are represented by the changing with time assessments of the method based on creative reconstructions, which method was applied during the postwar reconstruction in Poland. The trends in the conservation of monuments are also well illustrated by the evolution of the subject of diploma theses which are sent to competitions and the conservation methods used in these works. Thus, we can hope that thanks to comparative research such as the SURE and specialized competitions, the education of architecture students in the broadly understood field of conservation will be better adapted to the needs of graduates in a specific country and, due to the progressing globalization, it will provide them with a type of knowledge which can be used universally.

\section{References}

[1] Foster G., Saleh R., The Adaptive Reuse of Cultural Heritage in European Circular City Plans: A Systematic Review, Sustainability 2021, 13, 2889.

[2] Ost C., Carpentier F,. New Paradigm for Cultural Heritage in Europe. J. Contemp. Ital. Cult. 2017, 2, 258-265.

[3] Leeuwarden Declaration-Adaptive Re-Use of the Built Heritage: Preserving and Enhancing the Values of our Built Heritage for Future Generations. Adopted on 23 November 2018 in Leeuwarden. Available online: https://www.ace-cae. eu/fileadmin/New_Upload/_15_EU_Project/Creative_Europe/Conference_Built_Heritage/LEEUWARDEN_STATEMENT_FINAL_EN-NEW.pdf (accessed on 20 July 2021).

[4] Semes S.W., The Future of the Past: A Conservation Ethics for Architecture, Urbanism and Historic Preservation, W.W. Norton and Company, New York 2009.

[5] EAAE: Teaching Conservation/Restoration of the Architectural Heritage. Goals, Contents and Methods, Muso F., de Marco L. Eds., 2008. Available online: https://www.eaae.be/wp-content/uploads/2017/04/38_teaching-conservation-restoration-in-architectural-heritage.pdf (accessed on 20 July 2021).

[6] Szmygin B. (Eds), Best Practices Handbook. Contemporary Realities and Needs of Sustainable Urban Rehabilitation; Lublin University of Technology, Lublin 2017.

[7] Rules of the professor Jan Zachwatowicz international competition for the best master's-degree works performed at the institutions of higher learning concerned with the cultural heritage protection (2017). Available online: http://www. icomos-poland.org/images/Aktualności_pliki/Rules_2017_ZACHWATOWICZ_Competition.pdf (accessed on 20 July 2021).

[8] The Council of Europe and cultural heritage 1954-2000. Intergovernmental work: basic texts; Council of Europe Publishing, Strasbourg 2001; pp. 65-86.

[9] Polish Cultural Heritage legislation (2010). Available online: http://www.eui.eu/Projects/InternationalArtHeritageLaw/ Poland and http://www.coe.int/en/web/herein-system/poland (accessed on 20 July 2021).

[10] ACT of 20 July 2018 The Law on Higher Education and Science (2021). Available online: http://www.gov.pl/web/science/ constitution-for-science (accessed on 20 July 2021). 
[11] Bergan S., Matei L., The Future of the Bologna Process and the European Higher Education Area: New Perspectives on a Recurring Topic. In European Higher Education Area: Challenges for a New Decade, Curaj A., Deca L., Pricopie R. Eds.; Springer, Cham 2020; pp. 361-373. Available online: https://www.researchgate.net/publication/345766838_The_Future_of_the_Bologna_Process_and_the_European_Higher_Education_Area_New_Perspectives_on_a_Recurring_Topic (accessed on 20 July 2021).

[12] Kirschke K., Kirschke P., Komarzyńska-Świeściak E., Adaptive reuse of commercial and public buildings in Wroclaw Old Town in Poland. The occupant safety and comfort versus preservation of authenticity of monumental buildings. Commission of Architecture, Urban Planning and Landscape Studies 2018, 14, 3, pp. 24-41. Available online: http://bc.pollub. $\mathrm{pl} /$ dlibra/publication/13859/edition/13530/content?ref=desc (accessed on 20 July 2021).

[13] Verpoest L., Neuckermans H., De Jonge K., van Balen K., Presentation of the R. Lemaire Centre for Conservation. In EAAE: Teaching Conservation/Restoration of the Architectural Heritage. Goals, Contents and Methods, Muso F., de Marco L. Eds.; 2008; 38, pp. 33-37. Available online: https://www.eaae.be/wp-content/uploads/2017/04/38_teaching-conservation-restoration-in-architectural-heritage.pdf (accessed on 20 July 2021).

[14] Raymond Lemaire International Centre for Conservation (2021), Available online: https://set.kuleuven.be/rlicc/home (accessed on 20 July 2021).

[15] Schinkel-Wettbewerb (2021). Available online: https://www.aiv-berlin-brandenburg.de/wp-content/uploads/2020/10/ SWB2021_Auslobung.pdf (accessed on 20 July 2021).

[16] Sietko-Sierkiewicz D., Weclawowicz D., Kirschke P., Transformation TXL Architectus 2013, 33, 1, pp. 71-80. Available online: http://architectus.pwr.edu.pl/files/numery/33_07.pdf (accessed on 20 July 2021).

[17] Domus International Prize for Restoration and Conservation. Available online: https://www.archdaily.com/951377/viii-edition-domus-award-restoration-and-preservation-fassa-bortolo (accessed on 20 July 2021).

[18] Szczepański J., Sustainable monument preservation in architectural education, WTE\&TE, 2019, 17, 1, 42-47.

[19] Polski Komitet Narodowy ICOMOS 1965-2015, Pałubska K. ed.; PKN ICOMOS, Warszawa 2009.

[20] Zachwatowicz J., Program i zasady konserwacji zabytków. Biuletyn Historii Sztuki i Kultury 1946, 8, 1-2, pp. 48-52. Available online: https://digi.ub.uni-heidelberg.de/diglit/bhsk1946/0056 (accessed on 20 July 2021).

[21] Lubocka-Hoffmann M., The Post-War Rebuilding of Towns and Cities in Poland and the Retroversion of the Old Town in Elbląg. Ochrona Zabytków 2019, 274, 1, pp. 35-71. Available online: https://ochronazabytkow.nid.pl/wp-content/ uploads/2020/10/OZ_1-2019_02_Lubocka-Hoffmann.pdf (accessed on 20 July 2021).

[22] The Athens Charter for the Restoration of Historic Monuments (1931). Available online: http://www.icomos.org/en/ resources/charters-and-texts/179-articles-en-francais/ressources/charters-and-standards/167-the-athens-charter-for-the-restoration-of-historic-monuments (accessed on 20 July 2021).

[23] The Venice Charter for the Conservation and Restoration of Monuments and Sites (1964). Available online: http://www. icomos.org/charters/venice_e.pdf (accessed on 20 July 2021).

[24] Leeuwarden Declaration-Adaptive Re-Use of the Built Heritage: Preserving and Enhancing the Values of our Built Heritage for Future Generations. Adopted on 23 November 2018 in Leeuwarden. Available online: https://www.ace-cae. eu/fileadmin/New_Upload/_15_EU_Project/Creative_Europe/Conference_Built_Heritage/LEEUWARD EN_STATEMENT_FINAL_EN-NEW.pdf (accessed on 20 July 2021).

[25] Dołęga M., Kirschke K., Museum of Steam Locomotives - Steam Centre - the best project in the ICOMOS competition 2016. Architectus 2017, 51 (3), pp. 78-84. Available online: http://architectus.pwr.edu.pl/files/numery/51_07.pdf (accessed on 20 July 2021).

[26] LafargeHolcim Foundation. Prize Winning Projects in Sustainable Construction (2021). Available online: https://www. lafargeholcim-foundation.org/projects/all-projects?page $=6$ (accessed on 20 July 2021).

[27] Rozporządzeniem Ministra Nauki i Szkolnictwa Wyższego z 18 lipca 2019 r. w sprawie standardu kształcenia przygotowującego do wykonywania zawodu architekta (Regulation of the Minister of Science and Higher Education Dated 18 July 2019 on Teaching Standards Preparing to the Profession of Architect.). Available online in Polish: http://isap.sejm. gov.pl/isap.nsf/DocDetails.xsp?id=WDU20190001359 (accessed on 20 July 2021).

[28] Gawlak A., Prusiewicz-Sipińska E., Bonenberg W., Drawing Skills of Candidates for Architectural Studies vs. Learning Outcomes of Graduates. Comparative Research Based on the Example of The Faculty of Architecture Poznan University of Technology, Educ. Sci. 2021, 11 (7), 339.

[29] Rusnak M.A., Rabiega M., The Potential of Using an Eye Tracker in Architectural Education: Three Perspectives for Ordinary Users, Students and Lecturers, Buildings 2021, 11(6), 245.

[30] Della Spina, L Cultural Heritage: A Hybrid Framework for Ranking Adaptive Reuse Strategies. Buildings 2021, 11 (3), 132. 
[31] Vardopoulos I., Stamopoulos C., Chatzithanasis G., Michalakelis C., Giannouli P. and Eleni Pastrapa E., Considering Urban Development Paths and Processes on Account of Adaptive Reuse Projects, Buildings 2020, 10(4), 74.

[32] Lo Faro A., Miceli A., Sustainable Strategies for the Adaptive Reuse of Religious Heritage: A Social Opportunity Heritage, Buildings 2019, 9(10), 211.

[33] Elefante C., The greenest building is... one that is already built. Forum J. 2007, 21, pp. 26-38.

[34] Dyckhoff T., The Age of Spectacle: Adventures in Architecture and the 21 $1^{\text {st }}$-Century; Windmill-Books: London 2018.

\title{
Znaczenie ochrony dziedzictwa w edukacji architektonicznej na poziomie uniwersyteckim
}

\begin{abstract}
Przedmiotem artykułu są analizy dotyczące metod i efektów kształcenia architektoniczno-konserwatorskiego na poziomie uniwersyteckim, poczynione w oparciu o rezultaty badań projektu Erasmus + SURE oraz doświadczenie własne w tworzeniu i wdrażaniu programów nauczania konserwatorskiego na Wydziale Architektury Politechniki Wrocławskiej. Jako materiał porównawczy przedstawiono obserwacje dotyczące prac nadesłanych na międzynarodowy konkurs im. Jana Zachwatowicza (ICOMOS Poland), w którym oceniane są magisterskie projekty dyplomowe na temat ochrony i rewaloryzacji zabytków architektury. Jest to miejsce konfrontacji efektów nauczania na kierunkach architektura i konserwacja dziedzictwa, ukazujące różnice systemów i metod nauczania na uczelniach. Pozwoliło to na wyciągnięcie wniosków odnośnie kształcenia w specjalności architektura i urbanistyka, oraz na zarysowanie potrzebnych zmian programowych, z których część udało się wdrożyć w Polsce w 2020 r., poprzez wprowadzenie nowej podstawy programowej.
\end{abstract}

Keywords: konserwacja zabytków architektury, adaptacja budynków, edukacja architektoniczna, ochrona zabytków 